\title{
Constraints in Marketing of Vegetables in Kangra District of Himachal Pradesh, India
}

\author{
Jyoti Chaudhary ${ }^{1^{*}}$, Harbans Lal ${ }^{2}$ and Arti $^{2}$ \\ ${ }^{1}$ Department of Agricultural Economics, Institute of Agricultural Sciences, BHU, Varanasi, \\ $U P-221005$, India \\ ${ }^{2}$ Department of Agricultural Economics, Extension Education \& Rural Sociology, CSKHPKV, \\ Palampur, HP - 176062, India \\ *Corresponding author
}

\begin{tabular}{|c|c|}
\hline & $R A C T$ \\
\hline & \multirow{5}{*}{$\begin{array}{l}\text { India stands as the second largest producer of vegetables in world after China: it } \\
\text { contributes about } 14 \text { per cent to the world's vegetable production. The present study aimed } \\
\text { to analyse the constraints in marketing of vegetables in Kangra district of Himachal } \\
\text { Pradesh. The primary data on problems faced by farmers and market functionaries were } \\
\text { collected from } 60 \text { farmers selected from the } 10 \text { villages of Baijnath area of district Kangra } \\
\text { of Himachal Pradesh using two stage random sampling technique and } 20 \text { market } \\
\text { functionaries from Baijnath regulated market. The state Himachal Pradesh is divided into } \\
\text { ten notified market area. There are total } 59 \text { markets are functional in the state out of which } \\
10 \text { are principle regulated markets. Almost all the markets have the basic facilities but } \\
\text { other facilities like cold storage, grading sheds, mechanical grading and packing etc. } \\
\text { Which need to be there in the regulated markets are not available. Among the various } \\
\text { marketing problems faced by the farmers getting non-remunerative prices, high } \\
\text { transportation cost, labour scarcity and lack of nearby link roads were the major } \\
\text { constraints faced by the farmers. No separate prices for graded and non-graded produce, } \\
\text { lack of availability of cold storage in the market yards, etc. are some of the problems faced } \\
\text { by the market functionaries. The study thus emphasised on the strengthening the working } \\
\text { of regulated markets and the development of infrastructure in the market. }\end{array}$} \\
\hline & \\
\hline Artic & \\
\hline & \\
\hline & \\
\hline
\end{tabular}

\section{Introduction}

The efficient agricultural marketing system plays a key role in accelerating agricultural production and thereby promoting economic growth in developing countries. The progress of agricultural production cannot be regarded as complete without the sale of the produce in the markets. Agriculture is the main occupation in the India where the majority of the population depends on agriculture and allied sector. The marketing of agriculture produce has always been a tricky venture. The producers who have got timely marketing information regarding prices and arrivals can sell their produce at the right time and place for the right price gains from this venture while the rest suffer. Also, the excess of 
supply of agricultural produce during main season leads to low prices and driven farmers to despair. The Indian farmers typically depend heavily on middle men particularly in fruits and vegetables marketing. The producers and the consumers often get a poor deal and the middlemen control the market, but do not add much value. There is also massive wastage, deterioration in quality as well as frequent mismatch between demand and supply both spatially and over time (Gandhi and Namboodiri 2002). The traditional markets were mostly ruled by intermediaries who do not consider the interest of the primary producers.

Those intermediaries involved in various malpractices which aggravated the market problems. Thus, the need for regulating the marketing activities at the places of exchange was recognized. Often it has been realised that even after the establishment of regulated markets, the ideal conditions for marketing of agricultural produce do not existed. Agricultural marketing needs dynamism and sound information network. Once all these are put in place, farmers are assured of remunerative prices at minimum risk. An efficient marketing strategy is thus a key to prosperity for the farmers.

The majority (about $85 \%$ ) of the population in Himachal Pradesh belongs to marginal and small categories. In the event of this situation, the mere production of food grains cannot increase their income and vegetables here plays vital role in providing a source of employment and increase the standard of their living. The last few decades have witnessed a transformation in the state's agriculture from cereal-based subsistence agriculture to vegetable-dominated commercial agriculture with a significant shift in cropping pattern towards vegetables. The production of vegetable crops increased from 5 lakh metric tonnes in 1998-99 to 16.54 lakh metric tonnes in 2016-17. The vegetables being perishable, bulky and difficult in handling needs special attention as far as their grading, packing, storage and transportation is concerned. With this background, the study conducted mainly to examine the status of regulated markets and infrastructural facilities available in the markets, problems and constraints faced by the farmers and market intermediaries and suitable suggestions to improve the marketing of vegetables.

\section{Materials and Methods}

The study was based on both primary and secondary data. Secondary data pertaining to regulated markets and infrastructure facility available etc. were collected from various published/unpublished sources, reports of market committee, websites of agricultural marketing, etc. The primary data regarding various constraints faced by farmers in the marketing of vegetables were collected from 60 farmers drawn from 10 villages of the Baijnath area of district Kangra of Himachal Pradesh using two stage random sampling technique. In addition, 20 market functionaries including local trader, commission agent-cum wholesaler and retailer, were also selected for obtaining relevant information. The data were collected by survey method on well-designed pre-tested schedules by personal interview method. The data pertain to the agricultural year 2015-16.

Constraints were analysed using Garrett's ranking technique. The respondents were asked to rank the different constraints.

Garrett's formula for converting ranks into per cent was given by:

Per cent position $=\frac{100(\mathrm{Rij}-0.5)}{\mathrm{Nj}}$

Where, 
$\mathrm{R}_{\mathrm{ij}}=$ rank given for $\mathrm{i}^{\text {th }}$ factor by $\mathrm{j}^{\text {th }}$ individual

$\mathrm{N}_{\mathrm{j}}=$ number of factors ranked by $\mathrm{j}^{\text {th }}$ individual.

The per cent position of each rank was converted into scores referring to the table given by Garrett and Woodworth (1969). Finally, these problems were clubbed into high, medium and low severity categories as follow (Chauhan 2000):

Mean $(\overline{\mathrm{X}})$ plus standard error and above: High Mean $\left(\overline{\mathrm{X}}_{\text {) plus/ minus standard error: Medium }}\right.$ Mean $(\overline{\mathrm{X}})$ minus standard error: Low

\section{Results and Discussion}

\section{Regulated markets in the State}

Himachal Pradesh is a small state with a geographical area of $55673 \mathrm{sq}$. km. having 12 districts. In the past few years the state has emerged as a major fruits and vegetables producing state across the country. To deal with the substantial production of fruits and vegetables, the state is having a strong marketing network in the most of the districts (Table 1). The state is having 59 regulated markets, out of which 10 are principal market yards and 49 are market sub-yards and all the markets are under the regulation of Model Agricultural and Horticultural Produce Marketing Act (known as APMC Act, 2005).

The principal markets are situated in main yard in each district. In the district of Kinnaur and Lahaul-Spiti there are no principal markets and the principal markets of Shimla and Kullu act as principal markets for these two districts. District Solan is having the maximum number of market yards (12) followed by Kullu (9), Shimla (8) and Kangra (8). The district Chamba is having the only main market yard and there are no market subyards.
An efficient agricultural marketing system guarantees the farmers better prices for their farm produce. The regulated markets have been established by State Government and rules and regulations have been framed to improve marketing condition with a view to create fair competitive condition, to improve and enforce standard marketing practices and charges. The primary information about the market is given in Table 2. The Baijnath market is a small market and was regulated in the year 1990 while the principal market Kangra was regulated in year 1981 and is having yard area of 5359 sq. $\mathrm{m}$ and 7200 sq. $\mathrm{m}$ respectively. The coverage of Baijnath market is of $17 \mathrm{kms}$ whereas Kangra market is $15 \mathrm{Kms}$ radius and the number of villages covered is 228 and 496 in respective markets. The approximate number of producers annually coming to the markets is 25 and 50 .

\section{Infrastructural facilities in main market and sub market yards}

The infrastructural facilities available in the various markets are displayed in Table 3. It is evident from the table that most of the markets have basic facilities of the electronic display board, internal roads, parking, water supply and electricity. The facilities like grading/ packing sheds, cold storage/warehouses, mechanical grading and mechanical weighing were not available in the markets. The market was also lacking the facility of the telephone (STD/ISD), sanitary staff, post office, bank branch and input shops. The garbage disposal facility is available in all the markets except the Palampur market. The rest house for farmer's stay was available at Kangra, Baijnath and Jawalaji mandis only.

\section{Problems faced in marketing of vegetables}

The efficient production ensures lower per unit cost of output making it possible for a greater number of consumers to buy it while 
on the other hand efficient marketing system turns this possibility into reality benefiting both the producer and consumer. There are number of problems and constraints that render the present marketing system for agricultural commodities imperfect and inefficient.

\section{Problems faced by farmers}

Profit from growing of vegetables depending upon many factors i.e. stage and time of harvesting /picking, care taken in grading and packing, time taken in transportation, etc.

The farmers were inquired about the problems faced by them in marketing of their produce. Table 4 shows that among various problems experienced by the farmers, the getting of non- remunerative prices for their produce was the highly severe marketing problem experienced by majority of the farmers with a highest mean Garrett's score of 80.87 (Rank I). The next problem in importance was the carrying of the produce upto market was a time consuming and costly affair with mean Garrett's score of 75.95 (Rank II). The scarcity of labour and high wage rate and lack of nearby link roads upto the farm was another highly severe problem and ranked third and fourth on the basis of average Garrett's score of 71.95 and 69.57 , respectively.

On the basis of level of severity, under the category of medium, the problems experienced by the farmers were the location of the market at distant place, lack of timely availability of market information.

Table.1 Total Regulated markets in Himachal Pradesh (2016)

\begin{tabular}{|c|c|c|c|c|c|}
\hline \multirow[t]{2}{*}{$\begin{array}{l}\text { Sr. } \\
\text { No. }\end{array}$} & \multirow[t]{2}{*}{ District } & \multicolumn{2}{|c|}{$\begin{array}{l}\text { Principal market } \\
\text { yards }\end{array}$} & \multicolumn{2}{|r|}{ Sub market-yards } \\
\hline & & No. & Location & No. & Location \\
\hline 1 & Bilaspur & 1 & Bilaspur & 1 & Namhol \\
\hline 2 & Chamba & 1 & Chamba & - & - \\
\hline 3 & Hamirpur & 1 & Hamirpur & 2 & Nadaun, Jahu \\
\hline 4 & Kangra & 1 & Kangra & 7 & $\begin{array}{l}\text { NagrotaBagwan, Jassur, Baijnath, } \\
\text { Jaissinghpur, Jawalamukhi, Palampur, } \\
\text { Dharamshala }\end{array}$ \\
\hline 5 & $\begin{array}{l}\text { Kullu and } \\
\text { Lahaul-Spiti }\end{array}$ & 1 & Bhunter & 8 & $\begin{array}{l}\text { Kullu, Patlikul, Khegsu, Bandrol, Chauri } \\
\text { Vihal, Nirmand, Banjar, Shatt }\end{array}$ \\
\hline 6 & Mandi & 1 & $\begin{array}{l}\text { Mandi } \\
\text { (Kangni) }\end{array}$ & 5 & $\begin{array}{l}\text { Dhanotu, Takoli, Pali, Chailchowk, } \\
\text { Jogindernagar }\end{array}$ \\
\hline 7 & $\begin{array}{l}\text { Shimla \& } \\
\text { Kinnaur }\end{array}$ & 1 & Dhalli & 7 & $\begin{array}{l}\text { Theog, Koti, Rohru,Rampur, Bhattakoffer, } \\
\text { Kharapathar, Nerwa }\end{array}$ \\
\hline 8 & Sirmaur & 1 & $\begin{array}{l}\text { Paonta } \\
\text { Sahib }\end{array}$ & 7 & $\begin{array}{l}\text { Dadahu, Sataun, Kheri, Sarahan, Bhagthan, } \\
\text { Nahan, Rajgarh }\end{array}$ \\
\hline 9 & Solan & 1 & $\begin{array}{l}\text { Solan } \\
\text { (Kather) }\end{array}$ & 11 & $\begin{array}{l}\text { Chakki-Ka-mor, Arki, Dharampur, } \\
\text { Kandaghat, Kunihar, Saproon, Jagjitnagar, } \\
\text { Ramshaher, Parwanoo, Banali,Nalahar }\end{array}$ \\
\hline \multirow[t]{2}{*}{10} & Una & 1 & Una & 1 & Santoshgarh \\
\hline & Total & 10 & & 49 & \\
\hline
\end{tabular}

Source: www.agmarknet.nic.in 
Table.2 Salient features of principal market and Baijnath market

\begin{tabular}{|c|c|c|c|}
\hline $\begin{array}{l}\text { Sr. } \\
\text { No. }\end{array}$ & Particulars & Baijnath & Kangra \\
\hline 1 & Name of market & $\begin{array}{l}\text { Sub-market yard } \\
\text { Baijnath }\end{array}$ & $\begin{array}{l}\text { Principal market yard } \\
\text { Kangra }\end{array}$ \\
\hline 2 & Year of establishment & 1986 & 1981 \\
\hline 3 & Regulated/unregulated & Regulated & Regulated \\
\hline 4 & Year of regulation & 1990 & 1981 \\
\hline 5 & Name of the market legislation & $\begin{array}{l}\text { HP Agril and Hort } \\
\text { Produce Marketing (Dev } \\
\text { and Reg) Act } 2005\end{array}$ & $\begin{array}{l}\text { HP Agril and Hort } \\
\text { Produce Marketing (Dev } \\
\text { and Reg) Act } 2005\end{array}$ \\
\hline 6 & Location of the market & Town & Town \\
\hline 7 & Size of market (sq m) & 5359 & 7200 \\
\hline 8 & $\begin{array}{l}\text { Number of commodities notified } \\
\text { in Act }\end{array}$ & 131 & 131 \\
\hline 9 & $\begin{array}{l}\text { Number of commodities notified } \\
\text { in APMC Kangra }\end{array}$ & 99 & 99 \\
\hline 10 & Number of private yards & 0 & 0 \\
\hline 11 & $\begin{array}{l}\text { Distance from national highway } \\
(\mathrm{km})\end{array}$ & 1 & 1 \\
\hline 12 & Distance from nearest city $(\mathrm{km})$ & 0.5 & 1 \\
\hline 13 & Distance from bank branch $(\mathrm{km})$ & 0.5 & 1 \\
\hline 14 & Distance from post office $(\mathrm{km})$ & 0.5 & 2 \\
\hline 15 & $\begin{array}{l}\text { Distance from other competing } \\
\text { markets }(\mathrm{km})\end{array}$ & 16 & 18.5 \\
\hline 16 & Coverage of market/radius $(\mathrm{Km})$ & 17 & 15 \\
\hline 17 & Population served (No.) & 4450 & 9560 \\
\hline 18 & Villages served by market (No.) & 228 & 496 \\
\hline 19 & Number of shops & 7 & 25 \\
\hline 20 & $\begin{array}{l}\text { Number of producers coming to } \\
\text { the market per annum (No.) }\end{array}$ & 25 & 50 \\
\hline 21 & Number of auction platform (No.) & 1 & 1 \\
\hline 22 & $\begin{array}{l}\text { Commission to be charged by } \\
\text { agents }(\%)\end{array}$ & 5 & 5 \\
\hline 23 & Market fee (\%) & 1 & 1 \\
\hline 24 & Weighment (Rs./unit) & 1 & 1 \\
\hline 25 & Octroi/State tax (Rs./box) & 0 & 0 \\
\hline 26 & License fee (Rs.) & 300 & 300 \\
\hline 27 & License renewal fee (Rs.) & 100 & 100 \\
\hline 28 & Renewal period (year) & 1 & 1 \\
\hline
\end{tabular}

Source: www.agmarknet.nic.in 
Table.3 Regulated markets and provision of facilities in Kangra district

\begin{tabular}{|c|c|c|c|c|c|c|c|c|}
\hline A vailable Facilities & Kangra & Baijnath & Dharamshala & Jaissinghpur & Jassour & NagrotaBagwan & Palampur & Jawalaji \\
\hline $\begin{array}{l}\text { Information Notice Board/Electric Display } \\
\text { Board }\end{array}$ & $\sqrt{ }$ & - & - & $\sqrt{ }$ & $\sqrt{ }$ & $\sqrt{ }$ & $\sqrt{ }$ & $\sqrt{ }$ \\
\hline Canteen & $\sqrt{ }$ & $\sqrt{ }$ & $\sqrt{ }$ & $\sqrt{ }$ & $\sqrt{ }$ & $\sqrt{ }$ & $\sqrt{ }$ & $\sqrt{ }$ \\
\hline Restaurant & - & - & - & - & - & - & - & - \\
\hline Toilets & $\sqrt{ }$ & $\sqrt{ }$ & $\sqrt{ }$ & $\sqrt{ }$ & $\sqrt{ }$ & $\sqrt{ }$ & $\sqrt{ }$ & $\sqrt{ }$ \\
\hline Internal Roads & $\sqrt{ }$ & $\sqrt{ }$ & $\sqrt{ }$ & $\sqrt{ }$ & $\sqrt{ }$ & $\sqrt{ }$ & $\sqrt{ }$ & $\sqrt{ }$ \\
\hline Parking & $\sqrt{ }$ & $\sqrt{ }$ & $\sqrt{ }$ & $\sqrt{ }$ & $\sqrt{ }$ & $\sqrt{ }$ & $\sqrt{ }$ & $\sqrt{ }$ \\
\hline Fencing & - & $\sqrt{ }$ & $\sqrt{ }$ & $\sqrt{ }$ & - & - & $\sqrt{ }$ & $\sqrt{ }$ \\
\hline Post Office & - & - & - & - & - & - & - & - \\
\hline Bank & - & - & - & - & - & - & - & - \\
\hline Input/Sundry Shops & $\sqrt{ }$ & - & - & - & - & - & - & - \\
\hline Fire Extinguishers & - & - & - & - & - & - & - & - \\
\hline Rest house for farmers & $\sqrt{ }$ & $\sqrt{ }$ & - & - & - & - & - & $\sqrt{ }$ \\
\hline Drinking Water & $\sqrt{ }$ & $\sqrt{ }$ & $\sqrt{ }$ & $\sqrt{ }$ & $\sqrt{ }$ & $\sqrt{ }$ & $\sqrt{ }$ & $\sqrt{ }$ \\
\hline Electricity & $\sqrt{ }$ & $\sqrt{ }$ & $\sqrt{ }$ & $\sqrt{ }$ & $\sqrt{ }$ & $\sqrt{ }$ & $\sqrt{ }$ & $\sqrt{ }$ \\
\hline Auction Platform & $\sqrt{ }$ & $\sqrt{ }$ & - & $\sqrt{ }$ & $\sqrt{ }$ & $\sqrt{ }$ & $\sqrt{ }$ & $\sqrt{ }$ \\
\hline Grading and Analysing Laboratory & - & - & - & - & - & - & - & - \\
\hline Mechanical Graders & - & - & - & - & - & - & - & - \\
\hline Garbage Disposal System & $\sqrt{ }$ & $\sqrt{ }$ & $\sqrt{ }$ & $\sqrt{ }$ & $\sqrt{ }$ & $\sqrt{ }$ & - & $\sqrt{ }$ \\
\hline Sweeping Facilities & $\sqrt{ }$ & $\sqrt{ }$ & $\sqrt{ }$ & $\sqrt{ }$ & $\sqrt{ }$ & $\sqrt{ }$ & $\sqrt{ }$ & $\sqrt{ }$ \\
\hline Information Unit & $\sqrt{ }$ & $\sqrt{ }$ & - & $\sqrt{ }$ & $\sqrt{ }$ & $\sqrt{ }$ & $\sqrt{ }$ & - \\
\hline Extension Unity & $\sqrt{ }$ & - & - & - & - & - & - & - \\
\hline Market office building & $\sqrt{ }$ & $\sqrt{ }$ & $\sqrt{ }$ & $\sqrt{ }$ & $\sqrt{ }$ & $\sqrt{ }$ & $\sqrt{ }$ & $\sqrt{ }$ \\
\hline
\end{tabular}

Source: Market Committee Kangra, Himachal Pradesh 
Table.4 Problems faced by sample farmers in marketing of vegetables

\begin{tabular}{|c|c|c|c|c|}
\hline Problems & $\begin{array}{l}\text { Garrett } \\
\text { score }\end{array}$ & Mean & Rank & $\begin{array}{l}\text { Level of } \\
\text { Severity }\end{array}$ \\
\hline Non-remunerative prices & 4852 & 80.87 & I & \multirow[t]{5}{*}{ High } \\
\hline $\begin{array}{l}\text { Taking Produce to market costly and time } \\
\text { consuming }\end{array}$ & 4557 & 75.95 & II & \\
\hline Labour scarcity and high wage rate & 4317 & 71.95 & III & \\
\hline Lack of nearby link roads & 4174 & 69.57 & IV & \\
\hline Small lot to hire full vehicle & 4134 & 68.90 & V & \\
\hline Market at distant place & 3418 & 56.97 & VI & \multirow[t]{17}{*}{ Medium } \\
\hline Lack of timely availability of information & 3393 & 56.55 & VII & \\
\hline $\begin{array}{l}\text { High transportation charges and non-availability } \\
\text { of bus transportation at right time }\end{array}$ & 3359 & 55.98 & VIII & \\
\hline Deduction of undue charges in market & 3356 & 55.93 & IX & \\
\hline $\begin{array}{l}\text { Lack of reliable source of marketing } \\
\text { information/ marketing intelligence }\end{array}$ & 3250 & 54.17 & $X$ & \\
\hline Misleading information on prevailing prices & 3238 & 53.97 & XI & \\
\hline Delay payment by traders & 3201 & 53.35 & XII & \\
\hline No price for graded vegetables & 2971 & 49.52 & XIII & \\
\hline Costly packing material & 2825 & 47.08 & XIV & \\
\hline Grading by hand is time consuming and costly & 2722 & 45.37 & XV & \\
\hline No storage facility in market yard & 2504 & 41.73 & XVI & \\
\hline Lack of established market outlets & 2486 & 41.43 & XVIII & \\
\hline $\begin{array}{l}\text { Non-availability of institutional credits for } \\
\text { markets }\end{array}$ & 2483 & 41.38 & XVII & \\
\hline High rate of interest & 2478 & 41.30 & XIX & \\
\hline Road blockage during marketing season & 2398 & 39.97 & $\mathrm{XX}$ & \\
\hline Packing material not of good quality & 2259 & 37.65 & XXI & \\
\hline Scarcity of packing material & 2234 & 37.23 & XXII & \\
\hline Lack of boarding $\&$ lodging facility in market & 1949 & 32.48 & XXIII & \multirow[t]{3}{*}{ Low } \\
\hline Problem of parking of vehicle in market & 1453 & 24.22 & XXIV & \\
\hline Problem of space to unload the vehicle & 989 & 16.48 & XXV & \\
\hline Mean & 3000 & & & \\
\hline Standard deviation & 920.78 & & & \\
\hline
\end{tabular}


Table.5 Problems faced by market functionaries

\begin{tabular}{|l|c|c|c|c|}
\hline Problems & $\begin{array}{c}\text { Garrett } \\
\text { scores }\end{array}$ & Mean & Ranks & $\begin{array}{c}\text { Level of } \\
\text { severity }\end{array}$ \\
\hline No separate prices for graded and ungraded produce & 1424 & 71.20 & I & High \\
\hline Cold storage facility & 1344 & 67.20 & II \\
\hline Lack of lab analysis and mechanical grading & 1342 & 67.10 & III \\
\hline Labour scarcity and high wage rate & 1136 & 56.80 & IV \\
\hline Lack of grade specification & 1088 & 54.40 & V \\
\hline Inadequate information on demand and supply & 1022 & 51.10 & VI \\
\hline Lack of packing material and poor quality of packing & 804 & 40.20 & VII \\
\hline material & & 780 & 39.00 & VIII \\
\hline Poor market intelligence system in the state & 756 & 37.80 & IX \\
\hline Lack of sanitation \& cleaning of yard & 688 & 34.40 & X \\
\hline Lack of cooperation from officials & 502 & 25.10 & XI \\
\hline Parking, fencing, boarding and lodging facility & 434 & 21.70 & XII & Low \\
\hline Interference in the business by market committee & 943.33 & & \\
\hline Mean & 318.24 & & \\
\hline Standard Deviation &
\end{tabular}

The deduction of commission and undue charges in the market also categorized under the medium severe problems. The problems of delayed payment by the traders and offering of no higher prices for graded produce were pinpointed by farmers with mean Garrett's score of 49.52. Since these problems experienced by only few producers hence ranked lowest on the basis of average Garrett's score realized.

\section{Problem faced by market functionaries}

The problems faced by the market functionaries in marketing were also analysed and presented in Table 5. The problem of not getting separate prices for the graded and nongraded produce was ranked first by mean Garrett's score of 71.20. Lack of facility of cold storage in market, facility of lab analysis and mechanical grading were ranked as second and third problems experienced by the functionaries with the average Garrett's score 67.20 and 67.10, respectively. Labour scarcity and high wage rate were also reported by most of the functionaries and were categorized as medium severe problems (GS: 56.80) followed by the lack of grade specifications for grading of vegetables (GS: 54.40). The existence of poor market intelligence system in the state was also reported as one of the medium severe problems faced by the traders as they were devoid of getting the timely information regarding prices and arrivals of vegetables in the markets. The interference by market committee in their business was the less severe problem reported by them.

The vegetables are perishable in nature thus incurred high production and post-harvest losses and as such requires a well-developed marketing system. The study revealed that although there are good number of markets (59) established in the state and most of them were regulated but then also the facilities for efficient marketing of produce are lacking in the markets. The farmers face number of problems like not getting remunerative prices for their produce, marketing time consuming 
and costly process etc. which is the sign of inefficient working of the regulated markets, hence based on the study following suggestions have been made out:

The market committee need to strictly implement the various provisions of Marketing Regulation Act, and curbing malpractices of middleman like charging double commission from the traders as well as farmers and incorrect weighing of produce. The market committee should keep proper check on the functioning of market functionaries so that farmers get fair deal and remunerative prices.

The local and organic produce fetch premium price. Therefore, there should be separate auction platform in marketing for local produce and produce that comes from the other area. This will help in fetching better prices for farmer's quality produce.

Development of infrastructure, including roads, efficient transport and cold storage facilities may help the farmers as well as market functionaries for the better marketing of the agricultural produce.

\section{References}

Chauhan, S.K., and Mehta, P. 2002. Problems and constraints in vegetable marketing: A case study of Himachal Pradesh. The Bihar Journal of Agricultural Marketing 10(1): 25-30.

Gandhi, V.P., and Namboodiri, N.V. 2002. Fruit and vegetable marketing and its efficiency in India: A case study of wholesale markets in the Ahmedabad. IIMA (Indian Institute of Management). Ahmedabad, Gujarat

Garrett, H.E., and Woodworth, R.S. 1969. Statistics in Psychology and Education. Vakils Feffer and Simmons Pvt. Ltd., Bombay. p 329

Hosali, R., and Lokapur, S. 2015. Problems in production and marketing of cauliflower in Belgaum district of Karnataka. International Research Journal of Agricultural Economics \& Statistics. 6: 113-117

Roy, A., and Paul, S. 2015. Factors of vegetable marketing in West Bengal: Evidences and policy options. Indian Research Journal of Extension Education. 15(2): 62-67

\section{How to cite this article:}

Jyoti Chaudhary, Harbans Lal and Arti. 2018. Constraints in Marketing of Vegetables in Kangra District of Himachal Pradesh, India. Int.J.Curr.Microbiol.App.Sci. 7(11): 243-251. doi: https://doi.org/10.20546/ijcmas.2018.711.030 